\title{
Farklı Oranlarda Mürüdümük (Lathyrus sativus L.) Bitkisinin Bazı Meyve Posaları İle Silolanma Özelliklerinin Belirlenmesi
}

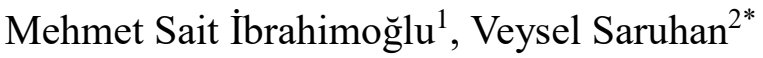 \\ ${ }^{1}$ Dicle Üniversitesi, Fen Bilimleri Enstitüsü, Tarla Bitkileri Bölümü, Diyarbakır, Türkiye (ORCID: 0000-0003-3391-3802) \\ 2 Dicle Üniversitesi, Ziraat Fakültesi, Tarla Bitkileri Bölümü, İstanbul, Türkiye (ORCID: 0000-0002-4906-8917)
}

(İlk Geliş Tarihi 1 Eylül 2019 ve Kabul Tarihi 29 Eylül 2019)

(DOI: $10.31590 /$ ejosat.618849)

\begin{abstract}
ATIF/REFERENCE: İbrahimoğlu, M.S., \& Saruhan, V. (2019). Farklı Oranlarda Mürüdümük (Lathyrus sativus L.) Bitkisinin Bazı
\end{abstract} Meyve Posaları İle Silolanma Özelliklerinin Belirlenmesi. Avrupa Bilim ve Teknoloji Dergisi, (17), 66-70.

Öz

Bu araştırma; Mürdümük (Lathyrus sativus L.) bitkisinin çeşitli oranlarda ilave edilmiş elma, armut ve limon meyveleriyle silolanması sonrası silaj kalite özelliklerinin belirlenmesi amacı ile yürütülmüştür. Bu amaçla yürütülen çalışmada; \%95 mürdümük+\%5 elma, $\% 90$ mürdümük+\%10 elma, $\% 85$ mürdümük+\%15 elma, $\% 95$ mürdümük+\%5 limon, $\% 90$ mürdümük+\%10 limon, $\% 85$ mürdümük+\%15 limon, $\% 95$ mürdümük $+\% 5$ armut, $\% 90$ mürdümük $+\% 10$ armut, $\% 85$ mürdümük $+\% 15$ armut olmak üzere toplamda 9 uygulama yapılmıştır. Silolanan bitkiler, ağzı kapalı hava almayacak şekilde plastik 2'şer lt'lik bidonlarda her uygulama için 3 tekerrürlü olacak şekilde hazırlanmıştır. Silajlar 60 gün fermantasyona bırakılmıştır. 60 günün sonunda bidonlar açılıp fiziksel (renk, koku, strüktür) ve kimyasal analizleri (kuru madde, ham kül, ham protein, ADF, NDF ve pH ) yapılıp Flieg puanı ve DLG puanı hesaplanmıştır. Yapılan tüm analizler sonucunda; ADF, Ham Protein (HP), ve pH değerleri arasındaki farklılıklar önemli bulunurken; Kuru madde (KM), Ham Kül (HK), NDF, Fleig Puanı (FP), renk, koku, strüktür ve DLG (Puan) değerleri arasında önemli farklılıklar bulunmamıştır. Elde edilen KM, HK, HP, ADF, NDF, pH ve flieg puanı (FP) değerleri sirasılyla ( \%20.33-24.18, \%10.19-11.37, \%25.59-28.14, \%28.09-35.12, \%32.41-38.67, 4.12-4.26, 76.22-85.12 ) arasında değişmiştir. Çalışma sonrasında elde edilen sonuçlar; mürdümük silolarına karbonhidrat kaynağı amacıyla meyve atıklarının katılması karışımın oranının \%85 mürdümük+\%15 limon olacak şekilde silolanmasının kalite özellikleri açısından daha uygun silaj olacağı önerilebilir.

Anahtar Kelimeler: Mürdümük, Silaj, Karışım, Fiziksel Özellikler

\section{Determination of Silvering Properties of Grasspea Plants (Lathyrus sativus L.) with Some Fruit Posas in Different Rates}

\begin{abstract}
This research the aim of the study was to determine the silolation characteristics of different apple, pear and lemon mixtures of Lathyrus sativus L. In this study conducted for this purpose; A total of 9 applications were made: grasspea $+5 \%$ apple, 95\% grasspea $+10 \%$ apple, \%90grasspea $+15 \%$ apple, $85 \%$ grasspea $+5 \%$ lemon, 95\%grasspea $+10 \%$ lemon, $80 \%$ grasspea $+15 \%$ lemon, $85 \%$ grasspea + $5 \%$ pear, 95\% grasspea $+10 \%$ pear, $90 \%$ grasspea $+15 \%$ pear The silaged plants were prepared as 3 repetitions in 2 liter plastic conisters which covered tightly so as no air intake. The physical examinations (color, smell and structure) and chemical analyses (dry matter, crude ash, crude protein, ADF, NDF, $\mathrm{pH}$ ) were done as well as having been calcuted the fleig scores, after the silage have been left for 60 days. As a result of analyzes; there were significant differences in crude protein, ADF, and pH values but there were no significant differences in color, smell, structure, flieg score (FP), NDF, dry matter (DM), crude ash, and DLG (score) values. The obtained values of dry matter (DDM), crude ash, crude protein, ADF, NDF, pH and flieg score were determined between 20,33-24,18\%, 10,19-11,37\%,
\end{abstract}

\footnotetext{
* Sorumlu Yazar: Dicle Üniversitesi, Ziraat Fakültesi, Tarla Bitkileri Bölümü, Diyarbakır, Türkiye, ORCID: 0000-0002-4906-8917, vsaruhan@dicle.edu.tr
} 
$25,59-28,14 \%, 28,09-35,12 \%, 32,41-38,67 \%, 4,12-4,26$ and 76,22-85,12 respectively. It can be suggested that the addition of fruit wastes to carbohydrate source in the silos is more suitable silage in terms of quality characteristics of the ratio of the mixture as $85 \%$ grasspea $+15 \%$ lemon

Keywords: Grasspea, Silage, Physical Properties, The Mixture

\section{Giriş}

Ülkemizin sanayisi, iklimi ve bitki örtüsüne bakıldığında isterse silaj ana materyali isterse de posa materyali olarak faydalanılabilecek pek çok artık ve yan ürün elde edilmektedir. Tarla ve bahçelerde toplanan seze ve meyvelerin artıkları ve üretim fazlası atıklar, ağaçların kabuk, sap, meyve ve yaprakları silaj yapımında kullanılabilecek ürünlerdir. Silaj olarak değerlendirilen bu ürünlerin uygulamada kullanılması; atıkların neden olabilecek çevre kirliliğini engelleme, yeni alternatif kaba yem kaynakları yaratma ve işletmenin finansal giderlerini azaltma konularında yarar sağlayacaktır.

Silaj, maliyet açısından ucuz ve yapımının kolay olmasından dolayı, hemen hemen her türlü bitkisel materyalden yapılabilmesi, fazla işçi ve işçiliğe ihtiyaç duyulmaması ve özellikle de besin maddeleri açısından kayıplarının minimum düzeyde olması avantajlarıyla ot kurutmak yerine tercih edilebilecek iyi bir alternatif yöntemdir (Filya, 2002).

Türkiye'de silaj ile ilgili yapılan çalışmalar mevcuttur. Örneğin; artık olarak kullanılan taze meyvelerden [elma (EP), şeftali (ŞP), kayısı (KP)] katkısız ve \%35 KM bulunan buğday samanı + \%0.1 ile karışım yapılarak silajlarda, EP, ŞP, KP karışımlarının KM düzeyleri \%14.92, \%14.21, \%15.98; posalı elma, şeftali ve kayısı posası karışımlarının KM düzeyleri \%34.11, \%35.03, \%32.93; pH düzeyleri EP, ŞP,KP silajlarında 3.91, 3.84, 3.87 ve katkılı silajlarında ise 4.20, 4.14, 3.18 olarak bulmuşlardır (Yalçınkaya v.dğr., 2012).

Diyarbakır koşullarında mürdümük silajının ortalama $\mathrm{pH}$ değeri 3.99, kuru madde oranı \%28.28, ADF oranı \%31.32, NDF oranı $\% 45.66$, ham protein oranı \%21.79, ham kül oranı $\% 8.74$ ve flieg puanını da 102.0 olarak tespit ettiklerini bildirmişlerdir (Seydoşoğlu ve Gelir, 2019). Tek ylllk baklagil yem bitkisi olan yem bezelyesi silajında, $\mathrm{pH}$ değeri 3.91 , kuru madde oran $\% 27.50$, ham protein oranı $\% 18.75$, ham kül oranı $\% 8.38$, flieg puanı 103.80, ADF oran1 \%32.65, NDF oranını ise $\% 42.48$ olarak rapor etmiş̧tir (Seydoşoğlu, 2019a). Benzer şekilde mürdümük ile arpa silaj karışımlarında, mürdümük silajının ham protein oranını $\% 22.96$, ham kül oranını $\% 8.50$ ve flieg puanını da 101.53 puan aldığını bildirmiş̧tir (Seydoşoğlu, 2019b).

Bu çalışmanın amacı, farklı oranlarda mürüdümük (Lathyrus sativus L.) bitkisinin bazı meyve posaları ile silolanma özelliklerinin belirlenmesidir.

\section{Materyal ve Metot}

GAP Uluslararası Tarımsal Araştırma ve Eğitim Merkezi tarafından tescil edilen Mürdümük (Lathyrus sativus 1.) çeşidi ve Diyarbakır semt pazarından alınan elma, armut ve limon meyvelerinin artıkları çalışmamızın materyallerini oluşturmaktadır. Deneme ekimi, Kasım ayında ekimi yapılmış olup, ot veriminin yüksek olması amacı ile Mayıs ayının ilk haftasında hasadı yapılmıştır. Silajlar farklı oranlarda $\% 95$ Mürdümük $\% 5$ Elma, $\% 90$ Mürdümük+\%10 Elma, $\% 85$ Mürdümük+\%15 Elma, $\% 95$ Mürdümük $+\% 5$ Armut, $\% 90$ Mürdümük $+\% 10$ Armut, $\% 85$ Mürdümük+\%15 Armut, , \%95 Mürdümük+\%5 Limon, \%90 Mürdümük+\%10 Limon, $\% 85$ Mürdümük $+\% 15$ Limon, olmak üzere toplamda 9 uygulama yapılmıştır. Materyaller belirtilen farklı oranlarda tartılıp, karıştırılıp 2 kg'lık 36 tane plastik bidona iyice sıkıştırılarak yerleştirilmiş̧ir. Bidonların hava almasını engellemek için iyice sıkıştırılmıştır. İyice sıkıştırılıp daha sonra kapatılan bidonlar patlama, kapağın firlatılıp atılması ve silajın hava alma risklerine karşı ağızları koli bandı yardımı ile iyice kapatılmıştır. Belirtilen oranlardaki tüm karışımlar silolandıktan sonra serin ve gölgelik bir ortamda 60 günlük süre ile bekletilmiştir. $\mathrm{Bu}$ süre sonunda bidonlar açılmış olup, fiziksel muayeneleri yapılarak $\mathrm{pH}$ değerleri belirlenmiştir. Daha sonra her bidondan örnekler alınarak $70{ }^{\circ} \mathrm{C}$ 'de kurutma dolabında 11-12 saat ön kurutma işlemi uygulanmıştır (Kaplan v.dğr., 2016). Her bir karışımdaki materyal 3 tekerrürlü olacak şekilde toplamda 36 kavanoza doldurulmuştur. Deneme süresince boyunca bidonlar haftalık periyotlarla kontrol edilip materyallerin durumları yakından takip edilmiştir. Araştırmada silaj $\mathrm{pH}$ değeri bir $\mathrm{pH}$ metre yardımıyla ölçülmüştür. Flieg ve DLG puanı ise Alman Tarım Örgüt’nün değerlendirmesine göre yapılmıştır. Kuru madde, ham protein, ham kül, ADF ve NDF özellikler ise NIRS cihazı ile tespit edilmiştir.

Yapılan araştırma sonu bulunan verilerin analizi yapılmış olup, ortalamalar arasındaki farklılıkların saptanmasında AÖF testi yapılmış ve değişim katsayıları (DK) \% olarak hesaplanmıştır.

\section{Araştırma Sonuçları ve Tartışma}

Tablo 1'e göre farklı oranlarda mürdümük + elma, mürdümük + limon, mürdümük + armut karışımları arasında pH değeri bakımından istatistiki olarak \%0.05 düzeyinde önemli farklılıklar bulunmuştur. En yüksek silaj pH değeri 4.26 ile $\% 15$ limon $+\% 85$ mürdümük karışımında bulunurken, en düşük $\mathrm{pH}$ değeri ise 4.12 ile $\% 10$ armut $+\% 90$ mürdümük karışımından elde edilmiştir. Uygulamalar açısından bakıldığında ise ortalama silaj pH değeri 4.18 olarak hesaplanmış olup, karışımların ortalaması silajın kalitesi açısından istenen bir değerdir.

Fermantasyon kalitesini ortaya koyan özelliklerden olan silajın $\mathrm{pH}$ değeri, silajdaki yemlerin yeterli düzeyde ekşimesini belirleyen önemli bir ölçüttür (İptaş ve Avcığlu, 1996). Silaj kalitesi belirlenirken fermantasyonu, pH değeri, amonyak ve organik asitlerin miktarları çok önemlidir. 
Tablo 1. Silajlartn $p H$, kuru madde, ADF ve NDF oranlart

\begin{tabular}{lllll}
\hline Uygulama & $\mathrm{pH}$ & Kuru madde oranı (\%) & ADF oran1 (\%) & NDF oran (\%) \\
\hline \%5 ELMA & $4.25 \mathrm{~A}$ & 22.69 & 31.82 & $37.29 \mathrm{AB}$ \\
\%10 ELMA & $4.17 \mathrm{BD}$ & 22.80 & 29.97 & $35.12 \mathrm{AC}$ \\
\%15 ELMA & $4.13 \mathrm{D}$ & 20.33 & 35.12 & $38.67 \mathrm{~A}$ \\
\%5 LiMON & $4.23 \mathrm{AB}$ & 24.18 & 30.43 & $33.08 \mathrm{C}$ \\
\%10 LiMON & $4.18 \mathrm{BD}$ & 23.13 & 28.09 & $32.46 \mathrm{C}$ \\
\%15 LiMON & $4.26 \mathrm{~A}$ & 20.74 & 31.59 & $37.10 \mathrm{AB}$ \\
\%5 ARMUT & $4.21 \mathrm{AC}$ & 20.89 & 31.11 & $35.28 \mathrm{AC}$ \\
\% 10 ARMUT & $4.12 \mathrm{D}$ & 22.55 & 29.95 & $34.65 \mathrm{BC}$ \\
\%15 ARMUT & $4.18 \mathrm{CD}$ & 21.94 & 31.97 & $38.37 \mathrm{AB}$ \\
\hline Ortalama & 4.18 & 22.14 & 31.11 & 35.78 \\
\hline LSD & 0.06 & Ö.D & Ö.D & 3.83 \\
\hline
\end{tabular}

Farklı oranlarda mürdümük + elma, mürdümük + limon, mürdümük + armut karışımları arasında kuru madde oranı ile ADF oranı bakımından istatistiki açıdan önemli farklılıklar bulunmazken, $\mathrm{pH}$ ve NDF oranı ise istatistiki yönden önemli bulunmuştur. Maksimum silaj KM oranı \%24.18 ile \%5 limon + \%95 mürdümük karışımından elde edilirken, minimum silaj kuru madde oranı ise $\% 20.33$ ile \%15 elma $+\% 85$ mürdümük karışımından elde edilmiştir. Uygulamalar açısından bakıldığında ise ortalama kuru madde oranı $\% 22.14$ olarak hesaplanmıştır.

Silajların kalitesinin belirlenmesinde önemli ölçütlerden birisi silaj kuru madde oranının belirlenmesidir. Yemin yaş ya da kuru numunelerinin ağırlığının belirli ölçüsünün, belirli sıcaklık derecesinde 1sıtılıp suyu buharlaştırıldıktan sonraki ağırlığı alınarak kuru madde oranı bulunur. Kuru madde oranının artması veya azalmasına bağlı olarak yem kalitesinin değişiklik gösterdiği yapılan değiş̧ik çalışmalarla kanıtlanmıştır.

Farklı oranlarda mürdümük + elma, mürdümük + limon, mürdümük + armut karışımları arasında ADF oranı istatistiki açıdan önemli farklılıklar saptanmamıştır. Maksimum ADF oranı \%35.12 ile \%15 elma + \%85 mürdümük karışımında bulunurken, minmum ADF değeri ise \%28.09 ile \%10 limon + \%90 mürdümük karışımından elde edilmiştir (Tablo 1). Uygulamalar açısından bakıldığında ise ortalama ADF oran $\% 31.11$ olarak hesaplanmıştır.

Kaba yemlerdeki sellülozun sindirilebilirliğini belirleyen kriterlerden biri ADF (ADF/ADS) oranıdır. Bu biçimde adlandırılmasının nedeni, sellüloz fraksiyonlarının kimyasal olarak belirlenmesinde nötr deterjan ve asit deterjanın çözücü olarak kullanılmasıdır. ADF, NDF (NDF/NDS) içerisinden hemi-selülozün çıkartılması ile bulunur. Bu sebeple bu yapı, yemin hazmedilirliği ve hayvan tarafından enerji alımı hakkında bize ipucu gösterir.

Farklı oranlarda mürdümük+elma, mürdümük+limon, mürdümük+armut karışımları arasında NDF değeri bakımından $\% 0,05$ derecede önemli farklılıklar bulunmuştur. Maksimum NDF oranı \%38.67 ile \%15 elma+ \%85 mürdümük karışımından elde edilirken, minimum NDF oranı ise \%32.46 ile \%10 limon+ \%90 mürdümük karışımından elde edilmiştir. Uygulamalar açısından bakıldığında ise ortalama NDF oranı \%35.78 olarak hesaplanmıştır.

Tablo 2. Silajların ham protein, ham kül, DLG ve flieg punları

\begin{tabular}{lllll}
\hline Uygulama & Ham protein oranı (\%) & Ham kül oranı (\%) & DLG & Flieg \\
& & & Puan & puanı \\
\hline \%5 ELMA & $27.78 \mathrm{AB}$ & 9.77 & 14.00 & 80.26 \\
\%10 ELMA & $27.21 \mathrm{AB}$ & 10.34 & 15.00 & 83.94 \\
\%15 ELMA & $26.35 \mathrm{BC}$ & 10.64 & 15.33 & 80.60 \\
\%5 LiMON & $27.78 \mathrm{BC}$ & 10.08 & 15.33 & 84.29 \\
\%10 LiMON & $28.14 \mathrm{~A}$ & 10.51 & 12.33 & 76.92 \\
\%15 LiMON & $26.29 \mathrm{BC}$ & 11.37 & 17.00 & 78.24 \\
\%5 ARMUT & $26.78 \mathrm{AC}$ & 10.51 & 14.00 & 85.17 \\
\%10 ARMUT & $25.59 \mathrm{C}$ & 9.41 & 15.00 & 82.76 \\
\%15 ARMUT & $27.10 \mathrm{AC}$ & 9.08 & 16.67 & 81.71 \\
\hline Ortalama & 27.01 & 10.19 & 14.67 & Ö.D \\
\hline LSD & 1.67 & O.D & Ö.D & \\
\hline
\end{tabular}


Kaba yemlerdeki selülozun hazmedilebilirlik belirleyen kriterlerden bir diğeri de NDF (NDF/NDS) oranıdır. Bu isimle adlandırılmasının nedeni, sellüloz (lifin) belirlenmesinde nötr deterjan ve asit deterjan çözücü olarak kullanılmasıdır. Kaba yemin hazmedilebilirliği, ADF ve NDF içerisinde bulunan ve çözünebilen maddelerin hazmedilebilirliği ve miktarı ile ilgili bir fonksiyondur. NDF hücre duvarında bulunan lifli karbonhidratlarını (hemi-selüloz ve selüloz), lignin, ligninleşmiş ve 1sı sonucu tahrip olmuş bir miktar protein ve silisyum bulundurur. Bu bize yemin özgül ağırlığı hakkında da bilgi veren bir değerdir.

Silaj pH değeri, kuru madde, ADF ve NDF oranları ile ilgili çalı̧̧malar incelendiğinde; bazı soya fasulyesi çeşitlerinde ortalama silaj $\mathrm{pH}$ değeri 5.75, kuru madde oranı $\% 31.49$, ADF oranı $\% 34.43$, NDF oranı ise $\% 43.75$ olarak rapor etmişlerdir (Kökten v.dğr., 2013). Bazı mısır çeşitlerinde ortalama silaj $\mathrm{pH}$ değeri 3.8, kuru madde oranı $\% 24.8$, ADF oranı ise $\% 32.9$ olarak tespit ettiklerini bildirmişlerdir (Seydoşoğlu ve Saruhan, 2017). Elde edilen sonuçlar, yukarıdaki araştırıcıların elde ettikleri bulgularla benzer olduğu belirlenmiş̧tir.

Farklı oranlarda mürdümük+elma, mürdümük+limon, mürdümük+armut karışımları arasında ham protein oranı açısısından istatistiki olarak \%0.01 düzeyinde önemli derecede farklılıklar bulunmuştur. Maksimum ham protein oran1 $\% 28.14$ ile $\% 10$ limon+ $\% 90$ mürdümük karışımında bulunurken, minimum ham protein oranı ise $\% 25.59$ ile $\% 10$ armut $+\% 90$ mürdümük karışımından elde edilmiş̧ir. Uygulamalar açısından bakıldığında ise ortalama han protein oranı \%27.01 olarak hesaplanmıştır.

Organik maddelerin yapısında bulunan ve nitrojen içeren tüm maddelere "ham protein" denir. Proteinlerin \%16'lk bir kısmını azot maddesi oluşturmaktadır. Ham protein; yapılan kimyasal analizler sonucu saptanan azot değerinin 6.25 katsayısı ile çarpılması ile sonuç bulunur. Yem kalitesinin belirlenmesinde önemli bir etken olan ham protein oranı yemin besin değeri hakkında önemli ipuçları vererek kullanılan bitkilerin hayvan beslenmesinde ne derecede etkili olacağını bizlere bildirmektedir.

Farklı oranlarda mürdümük + elma, mürdümük + limon, mürdümük + armut karışımlarında ham kül değeri istatistiki açıdan önemli derecede farklılıklara rastlanmamıştır. Maksimum ham kül oranı $\% 11.37$ ile $\% 15$ limon $+\% 85$ mürdümük karışımından elde edilirken, minimum ham kül oranı ise $\% 9.08$ ile $\% 15$ armut $+\% 85$ mürdümük karışımından elde edilmiştir. Uygulamalar açısından bakıldığında ise ortalama ham kül oranı \%10.19 olarak hesaplanmıştır. Farklı oranlarda mürdümük + elma, mürdümük + limon, mürdümük + armut karışımları arasında DLG puanı bakımından istatistiki açıdan önemli farklılıklar bulunmamıştır. En yüksek DLG puanı 17.00 ile \%15 limon $+\% 85$ mürdümük karışımında bulunurken, minimum DLG puanı değeri ise 12.33 ile $\% 10$ limon $+\% 90$ mürüdümük karışımından elde edilmiştir (Tablo 2). Uygulamalar açısından bakıldığında ise ortalama DLG puanı ise 14.67 olarak hesaplanmıştır. Farklı oranlarda mürdümük+elma, mürdümük+limon, mürdümük+armut karışımları arasında flieg puanı bakımından istatistiki bakımdan önemli farklılıklar bulunamamıştır. Maksimum flieg puanı 85.17 ile $\% 10$ armut $+\% 90$ mürdümük karışımında bulunurken, minimum flieg puanı ise 76.22 ile \%15 limon +85 mürdümük karışımından elde edilmiştir. Uygulamalar açısından bakıldığında ise ortalama flieg puanı ise 81.71 olarak hesaplanmıştır. Silajın ham protein ve ham kül oranı, DLG ile flieg puanı ile ilgili çalışmalar mevcuttur. Yem bezelyesi silajında ham protein oranı \%\%12.10-18.75, ham kül oranı \%8.21-8.38, flieg 104.20-111.50 puan olarak tespit etmiştir (Seydoşoğlu, 2019a). Mürdümük silajında ham protein oranı \%22.96, ham kül oranını ise \%8.50 olarak tespit etmiştir (Seydoşoğlu, 2019b).

\section{Sonuç}

Genel olarak elde edilen sonuçlar ışı̆̆ında; Mürdümük bitkisi ve elma, armut, limon meyveleri karışımlarından yapılan silolarda karışımın oranının \%85 mürdümük $+\% 15$ limon olacak şekilde silolanmasının kalite özellikleri açısından daha uygun silaj olacağı önerilebilir.

\section{Açıklama}

Bu çalışma, yüksek lisans tezinden üretilmiş olup, Dicle Üniversitesi Bilimsel Araştırmalar Projesi (ZİRAAT.17.005) tarafından desteklenmiştir.

\section{Kaynakça}

Filya, İ. 2002. Silaj yapımı. Silaj Bitkileri Yetiştirme ve Silaj Yapımı, Hasad Yayıncılık, Ankara.

İptaş, S., Avcıŏlu, R. 1996. Silajlarda Fermantasyon Ürünleri İle Nitelik Belirleme Yöntemleri Arasındaki İlişkiler. Türkiye 3. ÇayırMera ve Yem Bitkileri Kongresi, 17-19 Haziran. Erzurum.

Kaplan, M., Baran, Ö., Unlukara, A., Kale, H., Arslan, M., Kara, K., Buyukkılıç, B., Konca, Y., Ulas, A. 2016. The Effects of Different Nitrogen Doses and Irrigation Levels on Yield, Nutritive Value, Fermentation And Methane Characteristics Of Corn Silage. Turk J Field Crops. 21(1): 101-109.

Kökten, K., Boydak, E., Kaplan, M., Seydoşoğlu, S., Kavurmacı, Z. 2013. Bazı Soya Fasulyesi (Glycine max L.) Çeşitlerinden Yapılan Silajların Besin Değerlerinin Belirlenmesi. Türk Doğa ve Fen Dergisi, 2(2): 7-10.

Seydoşoğlu, S., Saruhan, V. 2017. Mısır Bitkisinde (Zea mays L.) Ekim Zamanı ve Çeşidin Silaj Kalitesi Üzerine Etkisi. Ege Üniversitesi Ziraat Fakültesi Dergisi, 54 (3):361-366.

Seydoşoğlu, S., Gelir, G. 2019. Farklı Oranlarda Karıştırılan Mürdümük (Lathrus sativus L.) ve Arpa (Hordeum vulgare L.) Hâsıllarının Silaj Özellikleri Üzerinde Bir Araştırma. Ĭgdır Üniversitesi Fen Bilimleri Enstitüsü Dergisi, 9(1): 397-406. 
Seydoşoğlu, S. 2019a. Farklı Oranlarda Karıştırılan Yem Bezelyesi (Pisum sativum L.) ve Arpa (Hordeum vulgare L.) Hâsıllarının Silaj Kalitesine Etkisinin Araştırılması. Ege Üniversitesi Ziraat Fakültesi Dergisi, 56(3). 297-302.

Seydoşoğlu, S. 2019b. Effects of Different Mixture Ratios of Grass Pea (Lathyrus sativus L.) and Barley (Hordeum vulgare) on Quality of Silage. Legume Research. DOI: 10.18805/LR-468.

Yalçınkaya, M.Y., Baytok, E., Yörük, M.A. 2012. Değişik Meyve Posası Silajlarının Bazı Fiziksel Ve Kimyasal Özellikleri. Erciyes Üniversitesi Veteriner Fakültesi Dergisi, 9(2): 95-106. 